\title{
A CONCEPÇÃO DE DEUS NA VISÃO DE DESCARTES
}

\section{Gabriel da Silva Silveiraa ; José Portugal dos Santos Ramos ${ }^{2}$}

1. Bolsista PIBIC/Fapesb, Graduando em Psicologia, Universidade Estadual de Feira de Santana, e-mail: gabriel_ssilveira@hotmail.com

2. Orientador, Departamento de Ciências Humanas e Filosofia, Universidade Estadual de Feira de Santana, email: domluso@gmail.com

PALAVRAS-CHAVE: Deus; Descartes; Natureza Perfeita.

\section{INTRODUÇÃO}

A presente pesquisa constitui uma investigação teórica acerca do que vem a ser a concepção de Deus no viés do filósofo moderno francês do século XVII René Descartes. Esta pesquisa teve como objetivo principal analisar o caminho trilhado por Descartes para chegar a concepção de Deus, fazendo análise de algumas de suas obras, de maneira mais aprofundada, do terceiro capítulo (terceira meditação) do livro Meditações Sobre a Filosofia Primeira (Meditationes de Prima Philosophia) (2004). Nessa meditação, Descartes traz a ideia de pensamento como algo que está no indivíduo e que somente o próprio pensamento poderia conceber a veracidade de todas as coisas que o indivíduo percebe, já que, para Descartes, as percepções através dos sentidos são enganadoras, haja visto que os sentidos são passíveis de erro do ponto de vista objetivo e as coisas concebidas pelo pensamento são completamente perfeitas do ponto de vista formal. Os objetivos específicos foram: a) esclarecer os conceitos de natureza perfeita e imperfeita trazidos pelo autor para fazer referência a si e a Deus; b) buscar o entendimento das realidades objetiva e formal e como Descartes insere Deus a partir dessas realidades; c) examinar a ideia de substância citada por Descartes em suas obras e como esta substância está contida nele.

\section{MATERIAL E MÉTODOS OU METODOLOGIA (ou equivalente)}

O método utilizado foi estritamente teórico sendo que suas principais fontes foram obras escritas por Descartes, em especial a obra Meditações Sobre a Filosofia Primeira (2004). Foram também utilizadas obras secundárias, redigidas por comentadores do autor principal (Descartes) com o intuito de trazer à baila interpretações variadas sobre o tema proposto com o objetivo de explicitar algumas questões, facilitando desta forma o entendimento do autor.

O Grupo de Estudos "Revoluções científicas nos séculos XVI e XVII: origens e ressonâncias do método proposto por Descartes em 1637" foi de importância fundamental para o andamento da pesquisa. Este é constituído pela equipe de docentes em conjunto com discentes de iniciação científica e discentes voluntários interessados em trilhar uma rotina de produção de conhecimento acerca de temas relativos a este projeto. A execução da pesquisa dispôs-se junto ao Núcleo de Estudos em Filosofia (NEF/UEFS), de maneira que não foi necessário o uso de recursos financeiros no que tange à infraestrutura. No que diz respeito ao material bibliográfico imprescindível à pesquisa, foi adquirido com recursos do próprio coordenador do projeto, através de arquivos digitais, através de recursos fornecidos pela Fundação de Amparo à Pesquisa do Estado da Bahia ou acessado à Biblioteca da Universidade Estadual de Feira de Santana (UEFS).

\section{RESULTADOS E/OU DISCUSSÃO (ou Análise e discussão dos resultados)}

$\mathrm{Na}$ terceira meditação da obra Meditações Sobre a Filosofia Primeira (Meditationes de Prima Philosophia) (2004), Descartes faz uma análise da existência de Deus, a julgar pelo título desta meditação, a saber, Sobre Deus, que ele existe. Nessa perspectiva, Descartes passa a considerar a aritmética e a geometria como sendo as únicas coisas indubitáveis, exatas. Contudo, o mesmo alega que, se posteriormente julgou que essas coisas pudessem ser postas em dúvida, foi por conta de algum Deus, 
que lhe teria concedido uma natureza que lhe enganasse, até mesmo acerca das coisas as quais considerava indubitáveis. Para conceber a ideia de Deus, é importante destacar que Descartes salienta por diversas vezes que exclui os sentidos, haja visto que os considera como fonte de erro e dúvida.

Antes de tudo, Descartes se aceita como coisa pensante, ou seja, "que duvida, que afirma, que nega, que entende poucas e ignora muitas coisas, que ama, que odeia, que quer, que não quer, que imagina também e que sente" (DESCARTES, 2004). Ao passo que pode ser considerado coisa pensante, ele busca saber se possui consigo o requisito necessário para que possa considerar algo como verdadeiro ou falso. Entretanto, quando algo é posto em dúvida, têm-se vazão para que seja verdadeiro, no momento em que esta dúvida seja eliminada. Em suma, todas as coisas, para serem consideradas verdadeiras precisam antes serem colocadas em dúvida. Este é o princípio do cogito ergo sum). Então, Descartes propõe uma regra geral: "é verdadeiro tudo o que percebo muito clara e muito distintamente" (DESCARTES, 2004).

Se então todas as coisas, para que sejam consideradas verdadeiras, precisam ser postas em dúvida a priori, logo, com Deus não pode ser diferente.

Assim, Descartes coloca, a existência de Deus em dúvida, mas diz que a opinião que o faz errar/duvidar é metafísica. Contudo, ao eliminar a dúvida, ele aceita a existência de Deus e a atribui a uma natureza perfeita e como a única coisa que não poderia provir dele (Descartes enquanto homem). Para Descartes, ele era uma natureza imperfeita e para que ele existisse necessariamente deveria haver uma natureza perfeita (Deus) que o criasse. Para ele, a ideia de Deus não poderia estar na sua natureza imperfeita, porque era "da natureza do perfeito não ser entendido pelo imperfeito" (DESCARTES, 2004).

A seguir, o autor levanta a hipótese de que o próprio Deus tivesse colocado em seus pensamentos a dúvida sobre as coisas mais evidentes e exatas, como a matemática e a geometria. Dessa forma, Deus seria uma espécie de "gênio maligno".

Para analisar a existência de Deus, o autor afirma precisar realizar uma divisão em seus pensamentos. Para ele as ideias poderiam ser classificadas a partir de dois tipos de realidade: a realidade formal e a realidade objetiva. A realidade formal, seria a essência da ideia, o que a caracterizaria, seria a ideia em si, metafísica. A realidade objetiva é representação da ideia alcançada pelos sentidos. Para conceber a ideia de Deus, ele necessita apenas da realidade formal, já que não há como ter acesso a Deus pelos sentidos. Entretanto, a ideia de Deus concebida por ele seria parcial, haja visto que Deus possui uma natureza perfeita, que não pode estar contida em sua totalidade na natureza imperfeita (Descartes).

Descartes exclui ainda, a ideia de que Deus o estivesse enganando, já que toda fraude e todo engano provém de um defeito e isso não poderia ser atribuído à uma natureza perfeita.

\section{CONSIDERAÇÕES FINAIS (ou Conclusão)}

A conclusão desta pesquisa segue com as seguintes premissas: a) Deus é uma natureza perfeita e indubitável e que os erros não provêm dele, visto que os erros são características de imperfeições; b) Deus criou Descartes e todas as coisas imperfeitas; c) Descartes só concebe a ideia de Deus de maneira formal e não objetiva; d) Descartes não poderia ser Deus, pois Deus só poderia ser concebido através da realidade formal, isto é, através de uma realidade existente no interior reflexivo do pensamento. Deus aqui é uma ideia, portanto não pode ser concebido no campo da realidade objetiva, a qual se tem acesso através dos sentidos e na qual o próprio Descartes é concebido. Sendo assim, Deus tem sua existência comprovada na filosofia cartesiana, sendo 
importante ressaltar que se trata de uma natureza racional, do ponto de vista filosófico e não de uma divindade religiosa.

\section{REFERÊNCIAS}

DESCARTES, René. 2003. Discurso do método. Tradução de Maria Ermantina Galvão. São Paulo: Martins Fontes.

2004. Meditações Sobre Filosofia Primeira. Campinas; Fausto Castilho. ALQUIÉ, Ferdinand. 1969. A Filosofia de Descartes. Tradução de Rodrigues Martins. Lisboa: Editorial Presença, 148 p.

COTTINGHAM, John. 1993. Dicionário Descartes. Tradução de Helena Martins. Rio de Janeiro: Jorge Zahar Editor,

GILSON, Étienne. 1987. Discours de la Méthode. Texte et Commentaire. Paris: Vrin. . 1951. Étudees sur le rôle de la pensée medieval dans la formation du système cartésien. Paris: vrin. . 1913. Index Scolastico-Cartésien. Paris: Librairie Félix Alcan.

GUEROULT, Martial. 1968. Descartes Selon L’Ordre des Raisons, v. I. Paris: Aubier. 2007. Lógica, arquitetônica e estruturas constitutivas dos sistemas filosóficos. In: Transformação/Ação: Revista de Filosofia/Universidade Estadual Paulista. Vol. 30, p. 235-246. São Paulo: Fundação Editora da UNESP. 1954. Métaphysique et physique de la force chez Descartes et chez Malebranche. In: Revue de Métaphysique et de Morale 59: 1-37.

HAMELIN, Octave. 1911. Le systhème de Descartes. Paris: Édité par L. Robin. PHILONENKO, Alexis. 1996. Reler Descartes. Tradução de Fernando Oliveira. Lisboa: Inst. Piaget.

RODIS-LEWIS, Geneviève. 1995. Descartes: Biographie. Paris: Calmann-Lévy. 